\title{
Optimization of the Process for Production of Enriched Ketchup
}

\author{
Elisa Basika (Corresponding author) \\ Department of Agricultural and Biosystems Engineering, Makerere University, P.O BOX \\ 7062 Kampala, Uganda
}

Tel: 256-787-909-944Ｅ-mail: ebasika21@gmail.com

\begin{abstract}
Julia Kigozi
Department of Agricultural and Biosystems Engineering, Makerere University, P.O BOX 7062 Kampala, Uganda
\end{abstract}

Tel: 256-772-609-649Ｅ-mail: jbulyakigozi@yahoo.com

\author{
Guston Tumuhimbise \\ Department of food science and technology, Makerere University, P.O BOX \\ 7062 Kampala, Uganda
}

Tel: 256-772-417-170_E-mail: Ampston23@gmail.com

Received: January 8, 2021 Accepted: March 24, $2021 \quad$ Published: April 27, 2021

doi:10.5296/jfs.v10i1.18567ＵRL: https://doi.org/10.5296/jfs.v10i1.18567

\begin{abstract}
Post-harvest losses of fruits and vegetables in Uganda are estimated at $30 \%$ which is approximately 4 billion shillings lost annually. This is due to limited knowledge on value addition and preservation technologies being unaffordable. This study sought to add value to fruits and vegetables with a focus on mangoes, tomatoes, and carrots produced locally. The study determined the effect of processing conditions and addition of fruits and vegetables on the physico-chemical and sensory properties of tomato ketchup. Tomatoes were replaced with mangoes in increments of $10 \%$ up to $50 \%$ while keeping carrot levels constant at $5 \%$. The best sensory properties were observed in the treatment that contained $15 \%$ mango. The
\end{abstract}




\section{$\triangle$ Macrothink}

Physico-chemical and sensory properties of ketchup were enhanced by the addition of fruits and vegetables up to $20 \%$. The sensory evaluation revealed that ketchup prepared by the addition of fruits and vegetables (local mangoes and carrots) was preferred as compared to the control sample at $0 \%$ mango. The color of ketchup was affected by the incorporation of mangoes and carrots and it was acceptable up to at 5\% carrot and 15\% mango including taste, appearance, flavor, mouthfeel and aroma. The best treatment was then subjected to different processing conditions at different holding times and temperatures of 5, 10 and 15 minutes at temperatures of $70,75,80,85,90$ and 100 degrees Celsius respectively. The best conditions were observed to be between $80^{\circ} \mathrm{C}$ and $85^{\circ} \mathrm{C}$ and 10 to 15 minutes holding time. It was also evident that time and temperature had a significant $(\mathrm{p}<0.05)$ effect on the Physico-chemical properties of ketchup.

Keywords: Ketchup, Mango, Carrots, Enriched, Tomatoe

\section{Introduction}

In Uganda, horticulture is one of the fastest-growing branches among the agricultural sectors (Ssemwanga, 2010), contributing $1 \%$ to the total world vegetable and fruits production. However, the fruit and vegetable consumption per capita per day in Uganda is still low (Ssonko, 2005 ) estimated at $200 \mathrm{~g} /$ day as compared to $490 \mathrm{~g}$ /day as recommended by FAO (2010). The low fruit and vegetable consumption is attributed to the seasonal changes which limit production and supply to only a few months of the year. Furthermore, post-harvest losses are estimated at 15-30 percent according to MAAIF (2016) due to high susceptibility to spoilage caused by the inefficient post-harvest technologies, aggravate the low fruit and vegetable consumption per capita per day in Uganda. Post-harvest losses are both quantitative and qualitative and they result in a measurable decrease in the monetary value of products. Fruit and vegetable production are also currently challenged by limited land, water, and increased weather variability due to climate change (La Pena \& Hughes 2007, Moretti, Mattos et al., 2010). These losses do not merely reduce the food available for human consumption but also cause negative externalities to society through costs of waste management, greenhouse gas production, and loss of scarce resources used in their production.

To achieve the Sustainable Development Goal (SDG) of food security and food availability, there needs to be reductions in the post-harvest losses at the farm, retail and consumer levels. There are several examples of promising practices that have been employed to reduce post-harvest losses (Boateng, 2016) which range from training in improved handling and storage hygiene to the use of hermetically sealed bags (Murdock, Margam, Baoua, Balfe, \& Shade, 2012) and household metallic silos (Olajide \& Oyelade, 2002) and are supported by enhancing the technical capabilities of local blacksmiths in silo construction.

Overcoming the perishability of crops, improving marketing, enhancing nutritional value and adding economic value through processing are the main strategic areas for reducing postharvest losses. There are different processing techniques employed and these can be divided into traditional and improved methods of processing. Examples of the commonly used processing methods include peeling and washing, grating, pressing/fermentation, sieving, frying/drying. An important aspect of processing is that it is often intended to prolong the preservation period of a product under ambient conditions. Besides permitting better preservation, processed products are easier to transport and create new opportunities for the 


\section{Macrothink}

farmer such as new markets. The different products as a result of the processing may include; sauces, wines, dried fruits and vegetables, juices, squashes, cordials, and fried products among others. The current growth in the middle class coupled with modernization of the Ugandan economy has seen changes in eating habits and food trends which have boosted the fast-food sector (Ayo, Bonabana-Wabbi, \& Sserunkuuma, 2012). This is evident in urban centers where fast food outlets have increased tremendously over the years.

A recent study by Sa et al. (2012) reveals that the majority of working-class Ugandans prefer to dine in restaurants to preparing meals at home. Consequently, they spend more on ready to eat meat products and fast foods that include chips, deep-fried chicken, sausages and deep-fried meat including pork. This has boosted consumption of sauces as an accompaniment to the meals. According to UNIDO (2004), sauces are among the products with the highest demand. Currently, the sauce market in Uganda is dominated by mainly products from tomatoes. This has not only seen a lack of diversity and high charges in times of tomato scarcity, but also a limitation in nutritional value that could be attained from other ingredients/ sauces. Furthermore, a venture into other ingredients would create a market for other agricultural products and boost farmers' incomes and the economy at a large. It is against such a background that the basis of this study is to formulate and optimize the process for production of an innovative tomato-mango-carrot ketchup.

\section{Material and Methods}

In this experiment, mangoes and carrots were added to tomatoes in different proportions and the functional properties including the nutritional, rheological and sensory characteristics of the resulting formulations were examined. The proportions according to Table 1 that gave the best properties were selected for further study.

\subsection{Sample Preparation}

All the fruits and vegetables needed for this research were procured from Kalerwe market in the suburbs of Kampala i.e. local mangoes, carrots, and tomatoes. The samples were washed to remove dirt, well-drained and rinsed in distilled water. They were placed in sterilized polythene bags and transported for juice extraction at the Food Technology Nutrition and Business Incubation Center (FTNBIC) at Makerere University Kampala (MUK). Each mango was washed thoroughly in tap water and washed again with treated water (boiled at $100{ }^{\circ} \mathrm{C}$ and cooled). The mangoes were peeled to remove the outer covering before being sliced into pieces ( $5 \mathrm{~cm}$ long) to remove the seeds. The pieces were then blended using an electric blender (Sayona model: SB 4233). Blending of the mangoes and carrots was done separately at short intervals from time to time to avoid overheating and excessive foaming. The juice was pasteurized at $62^{\circ} \mathrm{C}$ for 30 minutes (Aurand et al., 1987) and refrigerated at $4^{\circ} \mathrm{C}$. The carrot pulp was prepared according to the method of (Lan et al., 2005). The carrots were washed with tap water and peeled using Sodium hydroxide $(40 \mathrm{ga} / \mathrm{L})$ at $95^{\circ} \mathrm{C}$ for $1 \mathrm{~min}$ then washed again in tap water. This was followed by blanching in citric acid solution $(60 \mathrm{~g} / \mathrm{l})$ at $95^{\circ} \mathrm{C}$ for $5 \mathrm{~min}$ then cooling in iced water to inactivate their endogenous enzymes and soften their tissues. In the end, they were sliced and blended with the addition of distilled water 1:1 (v/w) and filtered on a cheesecloth under vacuum to get fresh juice. Mangoes, tomatoes, and carrots were mixed with decreasing amounts of tomatoes and increasing amounts of mangoes keeping the carrot levels constant. Treatment A was the control with $100 \%$ tomatoes, $0 \%$ mangoes and $0 \%$ carrots. The 


\section{Macrothink}

different treatments were then heated together with spices and held at boiling temperature for 20 minutes and packaged.

Table 1. Different treatment compositions

\begin{tabular}{lllllll}
\hline Treatment & A & B & C & D & E & F \\
\hline Tomatoes (\%) & 100 & 90 & 80 & 70 & 60 & 50 \\
Mangoes (\%) & 0 & 5 & 15 & 25 & 35 & 45 \\
Carrots (\%) & 0 & 5 & 5 & 5 & 5 & 5 \\
\hline
\end{tabular}

In the order of Tomatoes: Mangoes: Carrots $A=100: 0: 0 \quad B=90: 5: 5 \quad C=80: 15: 5 \quad D=70: 25: 5$ $E=60: 35: 5 \quad F=50: 45: 5$.

The treatments in Table 1 above were then each subjected to sensory evaluation and their functional properties measured in the laboratory. The most preferred formulation with the best nutritional properties according to proximate analysis was chosen for further investigations. The best formulation was then subjected to different processing conditions i.e. time and temperature. The nutritional and rheological properties will then be measured and analyzed to determine the best processing conditions for ketchup without compromising the nutritional value.

\subsection{Determination of Nutritional Properties}

\subsubsection{Total Solids}

Total solids were determined by measuring $10 \mathrm{ml}$ of the treatments and weighed into a $50 \mathrm{~mm}$ diameter flat bottomed petri dish. The treatment will then be evaporated on a boiling water bath until it is solidified and was dried for two and a half hours in an oven at a temperature of $100^{\circ} \mathrm{C}$. It will then be cooled in a desiccator and weighed. The difference in weight between the initial and final weight was recorded as total solids (AOAC, 1990). Measurements were taken in triplicates.

\subsubsection{Ash Content}

The sauce was heated in a water bath to dry most of the moisture content before ashing is determined. The dry ashing method following AOAC (1990) was used for the sauce treatments. Ten milliliters of the treatment were weighed into a crucible and heated with a furnace, at $550^{\circ} \mathrm{C}$ overnight. The crucible was taken out of the burner and cooled in a desiccator.

$$
\text { ASH }(\%)=\frac{\text { weight of ash }}{\text { Weight of sample }} \times 100
$$

\subsubsection{Total Soluble Solids}

The total soluble solids of the treatments were determined with a refractometer instrument at a temperature of $20^{\circ} \mathrm{C}$ and the refractive index obtained was used to find the degree Brix from a chart and was compared with the degree Brix as described by AOAC. (1990). the results were taken in triplicates. 


\section{Mll Macrothink}

\subsubsection{Titratable Acidity}

For titratable acidity, ten milliliters $(10 \mathrm{ml})$ of the sauce formulated was mixed with $100 \mathrm{ml}$ distilled water. The mixture will then be titrated against $0.1 \mathrm{M} \mathrm{NaOH}$ using $1 \%$ phenolphthalein as an indicator. The acidity was calculated based on citric acid.

\subsubsection{Vitamin C}

Vitamin $\mathrm{C}$ of the different samples was determined according to the method below;

Balance, capacity 100 to 200 accuracy 3 g-10 g with a set of analytical weights, Tared beakers or weighing pans, Filter paper, fluted, Whatman No. 12, $12.5 \mathrm{~cm}$ or the equivalent, Funnel, glass $65 \mathrm{~mm}$, Beakers, $50 \mathrm{ml}$ to $100 \mathrm{~min}$, Erlenmeyer flasks, $50 \mathrm{~min}$, Pippete, volumetric, $5 \mathrm{~mL}$, $10 \mathrm{ml}$ and $20 \mathrm{ml}$, Burette, $10 \mathrm{~min}$, graduated in $0.05 \mathrm{~min}$, Burette support and Volumetric flask, $100 \mathrm{~min}$.

Dissolve $50 \mathrm{mg}$ of sodium 2, 6-dichloroindophenol and $20 \mathrm{mg}$ of sodium bicarbonate in warm water and filter into a $100-\mathrm{mL}$ volumetric flask using a small filter paper. Wash the filter paper until the color is completely removed. Pipette $25 \mathrm{~min}$ juice into a $100-\mathrm{mL}$ volumetric flask immediately after opening tie container, and makeup to volume with 3 percent metaphosphoric acid after each time swirling or rotating the flask to bring air bubbles to the surface. If necessary, add a drop of capryl alcohol to break the foam. Pipette a $10 \mathrm{~mL}$ aliquot of filtrate (from $5 \mathrm{~min}$ to $20 \mathrm{~min}$ may be used if desired) into a 50 min Erlenmeyer flask. Titrate rapidly with the dye solution until a definite pink color is obtained which persists for about $15 \mathrm{~s}$.

In the case of liquid products, results are preferably expressed as milligrams of ascorbic acid per 100 min the results can be calculated using the following formula:

$$
\text { Ascorbic acid (mg per } 100 \mathrm{gm} \text { or ml) }=\frac{\mathrm{Ta} \times \mathrm{D} \times 100}{\mathrm{Sa}}
$$

$\mathrm{Ta}$ is number of mills titrated, $\mathrm{D}$ is the dye factor which is equal to milligrams of ascorbic acid equivalent of dye and $\mathrm{Sa}$ is Number of mills of original treatment titrated.

\subsection{Determination of Rheological Properties}

The rheological aspects which include viscosity and syneresis were determined according to procedure as stated in the sections below;

\subsubsection{Viscosity}

Relative Viscosity was determined in an Ostwald viscometer at $25^{\circ} \mathrm{C}$ with distilled water as a control. It was expressed in centipoises (cPs).

\subsubsection{Syneresis}

Syneresis of ketchup treatments was determined by centrifuge (3-16 L Sigma, Germany). A measured amount of ketchup was taken in a centrifuge tube and centrifuged at 2200 and $5000 \mathrm{~g}$ respectively, at $20^{\circ} \mathrm{C}$ for $10 \mathrm{~min}$ (Şahin and Özdemir 2007). The supernatant was discarded, and the remaining part was weighed. The serum separation was measured after each week for one month. The serum separation rate was calculated from (Şahin \& Özdemir, 2007).

$$
\text { Syneresis }(\%)=\text { Serum weight } / \text { Ketchup weight } \times 100
$$

\subsection{Sensory Properties}

The formulated mango-carrot ketchup was subjected to sensory evaluation using a non-trained panel of 50 people consisting students and staff of the school of Food Technology, Nutrition 


\section{MInstitute Macrothink $_{\text {Int }}$}

and Bioengineering between ages of 20 to 50 years. Six coded samples (A, B, C, D, E and F) were judged by the panelists for; appearance, color, taste, flavor, aroma, mouthfeel and overall acceptability using a 9 -point hedonic scale $(1=$ dislike extremely, $2=$ dislike very much, $3=$ dislike moderately, $4=$ dislike slightly $5=$ neither like or dislike, $6=$ like slightly, $7=$ like moderately, $8=$ like very much, 9= like extremely). Ketchup samples were provided with potato chips to the panelists one week after production. Panelists were requested to rinse their mouth with water before, in between and after testing each ketchup sample

\subsection{Data Analysis}

Data on nutrient content, sensory analysis and rheological parameters, was obtained and checked for normality. $\mathrm{R}$ software was used to perform descriptive statistical analysis including getting the means and standard errors. ANOVA was used at $\alpha=0.05$ to test for differences in parameters for the various mixing ratios, time and temperature values in the data collected. Duncan Multiple Range Test was used to ascertain statistical significance between groups and to determine whether different ratios, times and temperatures or the interactions between the two factors had an effect on the nutritional content and rheological parameters. Nutrient prediction models were done and correlation between factors were carried out in R studio.

The best formulation was established by comparison of nutritional properties, sensory properties and rheological properties of the different formulations. The formulation with the best properties was considered for further analysis in objective two to determine the effect of processing conditions on ketchup.

\subsection{Statistical Analysis}

The best formulation from objective one based on the nutritional, sensory and rheological properties was selected and considered for further analysis to determine the effect of processing conditions on the quality of ketchup. The temperature time combinations in Table 2 below were determined basing on how the different ingredients i.e tomatoe, carrots, mangoes, behave when subjected to different temperatures (Castro, Teixeira, Salengke, Sastry, \& Vicente, 2004; Mrad, Boudhrioua, Kechaou, Courtois, \& Bonazzi, 2012; Sánchez, Baranda, \& de Marañón, 2014; Saravacos, 1970). Material preparation and measurement of the nutritional and rheological properties for this section will be done as elaborated in section 错 误!未找到引用源。 above.

Table 2. The experimental setup

\begin{tabular}{llll}
\hline \multicolumn{3}{l}{ Holding time } & \\
\hline temperature & $\mathbf{5}$ minutes & $\mathbf{1 0}$ minutes & $\mathbf{1 5}$ minutes \\
\hline 70 & & & $\mathrm{~T} 3$ \\
75 & $\mathrm{~T} 1$ & $\mathrm{~T} 2$ & $\mathrm{~T} 6$ \\
80 & $\mathrm{~T} 4$ & $\mathrm{~T} 5$ & $\mathrm{~T} 9$ \\
85 & $\mathrm{~T} 7$ & $\mathrm{~T} 8$ & $\mathrm{~T} 12$ \\
\hline
\end{tabular}




\begin{tabular}{llll}
\hline 90 & T13 & T14 & T15 \\
100 & T16 & T17 & T18 \\
\hline
\end{tabular}

$\mathrm{T}=$ Treatment.

\subsection{Acceptance Analysis}

Analysis of all the data obtained was done using the R studio, MATLAB and excel packages.

\section{Results and Discussion}

\subsection{Enhancement of the Functional Properties of Tomato Ketchup by Incorporation of Carrots and Mangoes}

On addition of mangoes and carrots to tomato ketchup, there was a drastic increase in the levels of ascorbic acid. The levels of ascorbic acid had their lowest levels in treatment A with 100\% tomato and their peak in treatment $\mathrm{F}$ in which $50 \%$ of the tomatoes were replaced with mangoes and carrots. According to Haugen et al. (2018), it is recommended that a person consumes about 5 to $10 \mathrm{mg}$ of vitamin $\mathrm{C}$ daily to prevent the manifestation of scurvy and a higher dose of not less than $120 \mathrm{mg}$ daily is recommended in the elderly (Gillberg et al., 2018). For a human being in perfect health a daily intake of $100 \mathrm{mg}$ is sufficient to circulate the neutrophils, leukocytes and other body tissues (Naidu, 2003). The average consumption of ketchup per meal is about $100 \mathrm{~g}$ which translates to about $160 \mathrm{mg}$ of ascorbic acid according to Table 3 below. Both starch and soluble sugars followed the same trend having their peak in treatment $\mathrm{C}$ and total carotenoids decreased drastically from treatment $\mathrm{A}$ and leveled at treatment $\mathrm{B}$, increased slightly at $\mathrm{D}$ before decreasing gradually towards. The recommended intake of $\beta$-carotenes varies substantially to F. The European Food Safety Authority (EFSA) recommends a daily intake of not more than $15 \mathrm{mg}$ while the UK stands at a maximum of $7 \mathrm{mg}$ per day (Eggersdorfer \& Wyss, 2018).

Total sugars (starch +soluble sugars) were highest in treatment $\mathrm{C}$ and lowest in treatment D. Treatment $\mathrm{F}$ was generally more acidic with a $\mathrm{pH}$ of 3.57 while $\mathrm{A}$ was the less acidic with a $\mathrm{pH}$ of 3.88. There was no significant difference $(p \leq 0.05)$ in the ash content of all treatments. There was also a general increase in fat content from treatment $A$ to $F$, however, there was a drop at D before a drastic increase at treatment $\mathrm{E}$.

\subsection{Nutritional Properties}

Table 3. Nutritional and rheological properties after addition of mangoes and carrots

\begin{tabular}{|c|c|c|c|c|c|c|c|c|c|c|}
\hline Treatment & T.A & $\begin{array}{l}\text { Vit. C } \\
(\mathrm{mg} / 100 \\
\mathrm{g})\end{array}$ & $\begin{array}{l}\text { S.S } \\
\text { (glucose/ } \\
100 \mathrm{~g} \text { ) }\end{array}$ & $\begin{array}{l}\text { Starch } \\
\text { (glucose/ } \\
100 \mathrm{~g} \text { ) }\end{array}$ & $\mathrm{pH}$ & $\begin{array}{l}\text { M.C } \\
(\%)\end{array}$ & $\begin{array}{l}\text { A.C } \\
(\%)\end{array}$ & T.C/100g & $\begin{array}{l}\% \text { Fat } \\
\text { content }\end{array}$ & $\begin{array}{l}\text { Viscosity } \\
\mathrm{cP}\end{array}$ \\
\hline A & 1.66 & 150.4 & 13.23 & 6.18 & 3.88 & 76.65 & 2.69 & 1.21 & 0.067 & 84131 \\
\hline B & 1.46 & 162.8 & 17.83 & 6.70 & 3.80 & 75.87 & 2.54 & 0.69 & 0.097 & 108612 \\
\hline $\mathrm{C}$ & 1.73 & 163.4 & 20.51 & 6.96 & 3.70 & 71.41 & 2.44 & 0.68 & 0.097 & 183568 \\
\hline D & 1.50 & 185.5 & 21.49 & 7.55 & 3.76 & 74.54 & 2.50 & 0.74 & 0.063 & 191725 \\
\hline
\end{tabular}




\begin{tabular}{lllllllllll}
\hline $\mathrm{E}$ & 1.50 & 178.9 & 22.14 & 7.45 & 3.73 & 73.46 & 2.67 & 0.56 & 0.124 & 241994 \\
$\mathrm{~F}$ & 1.51 & 248.3 & 26.34 & 8.35 & 3.57 & 73.19 & 2.47 & 0.46 & 0.143 & 270636 \\
\hline
\end{tabular}

T.C-total carotenoids S.S- Soluble sugars M.C-moisture content A.C-Ash content T.A-titratable acidity.

In the order of Tomatoes: Mangoes: Carrots $A=100: 0: 0 \quad B=90: 5: 5 \quad C=80: 15: 5 \quad D=70: 25: 5$ $\mathrm{E}=60: 35: 5 \mathrm{~F}=50: 45: 5$.

There was a gradual increase of ascorbic acid on addition from treatment $\mathrm{A}$ to treatment $\mathrm{F}$ and this is attributed to the increasing levels of the quantity of mango pulp per treatment from A to $\mathrm{F}$ according to

Table 3 (Shah, 2010). There was also a gradual decrease in the levels of total carotenoids from treatment $\mathrm{A}$ to $\mathrm{F}$ which is attributed to the decreasing levels of tomato pulp from treatment A to F. tomatoes have very high concentrations of carotenoids mainly lycopene (Shi et al., 2004) which is responsible for their red color. The total sugars increased substantially with addition of mangoes from treatment $\mathrm{A}$ to treatment $\mathrm{C}$ where then gradually to $\mathrm{E}$ before increasing rapidly to $\mathrm{F}$ as seen in. The increase in sugars is attributed to the increase in levels of mangoes and addition of carrots. Mangoes are characterized with high levels of soluble sugars and very low levels of starch which are responsible for their sweetness (Malundo et al., 2001). According to Table 3 the levels of titratable acidity decreased slightly with addition of mangoes from treatment A to F. this can be attributed to the buffering nature of ripe mangoes due to presence of the citrate cleavage enzyme responsible for ripening. The levels of citrate cleavage enzyme are stimulated by the levels of glucose, fructose and fatty acids (Oleic acid and palmitic) (Mattoo \& Modi, 1970). The following models can be used to predict the behavior of the different nutrition parameters with increasing levels of mangoes;

Total carotenoids $=1.10148$ mangoes $* 0.011657$

$$
\mathrm{R}^{2}=0.707
$$

Viscosity $=84338+$ Mangoes $* 3830.9$

$$
\mathrm{R}^{2}=0.969
$$

Vitamin $C=141.56+$ Mangoes $* 1.5997 \quad \mathrm{R}^{2}=0.731$

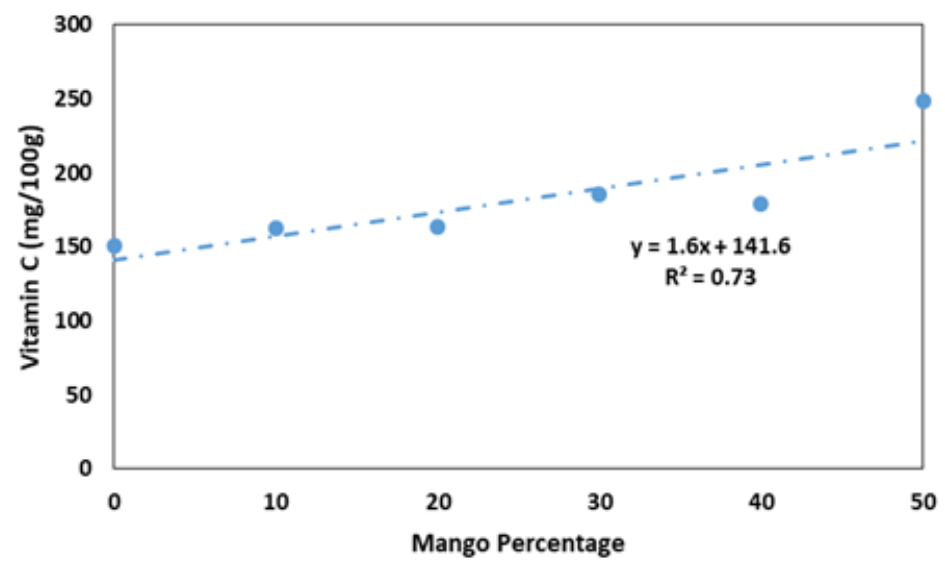

Figure 1. Relationship between vitamin $\mathrm{C}$ and percentage of mangoes 


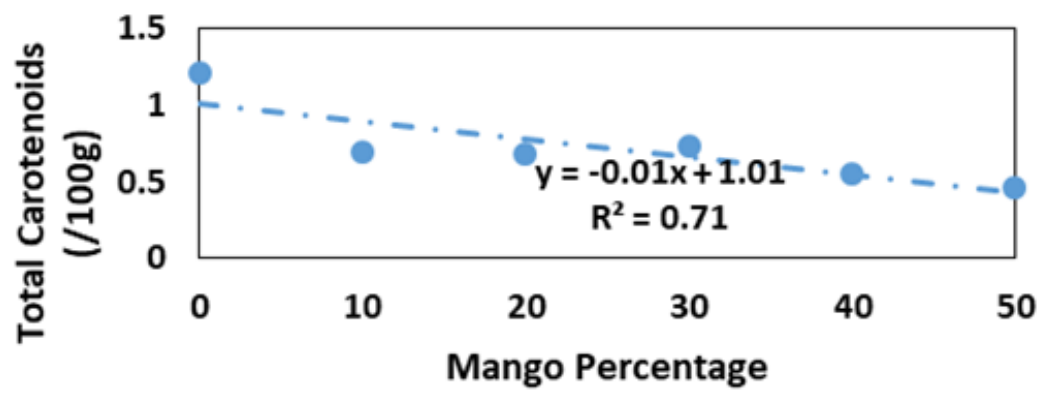

Figure 2. Relationship between total carotenoids and percentage of mangoes

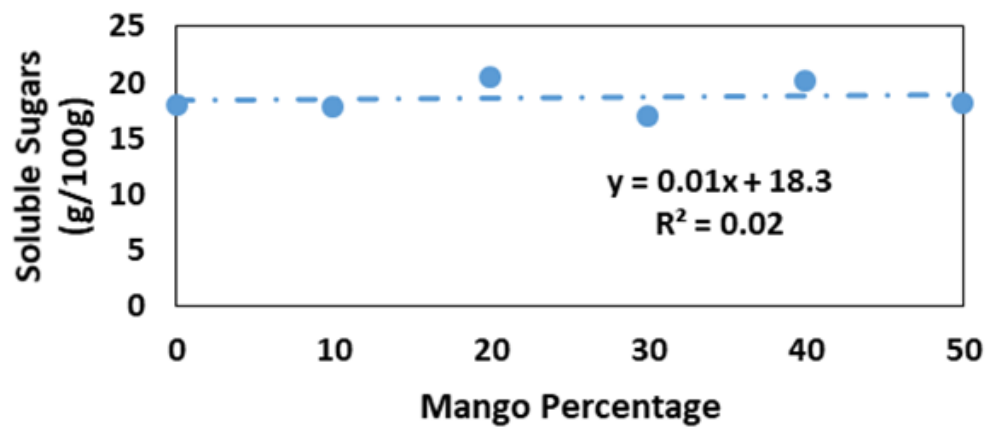

Figure 3. Relationship between soluble sugars and percentage of mangoes

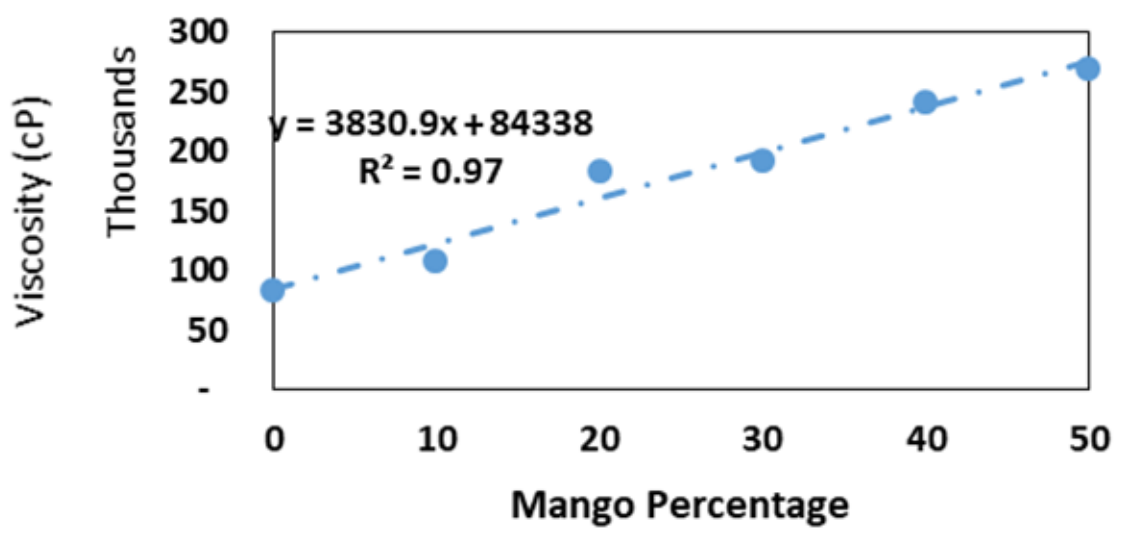

Figure 4. Relationship between viscosity and percentage of mangoes

\subsection{Sensory Properties}

In this section, results obtained from sensory analysis done using a non-trained panel of 50 participants whose responses were recorded are presented. A total of six samples were provided to each participant and responses on appearance, aroma, color, taste, flavor, mouthfeel and overall acceptability were recorded and analyzed. 
Table 4. Cumulative values of sensory evaluation for the different treatments

\begin{tabular}{lllllll}
\hline & A & B & C & D & E & F \\
\hline Appearance & 385 & 342 & 307 & 299 & 269 & 204 \\
Color & 390 & 340 & 320 & 284 & 269 & 200 \\
Taste & 360 & 334 & 353 & 312 & 317 & 272 \\
Flavor & 350 & 299 & 362 & 307 & 266 & 220 \\
Aroma & 350 & 311 & 371 & 303 & 257 & 233 \\
Mouthfeel & 327 & 276 & 314 & 304 & 283 & 210 \\
Overall acceptance & 362 & 294 & 376 & 292 & 272 & 246 \\
& $\mathbf{2 5 2 4}$ & $\mathbf{2 1 9 6}$ & $\mathbf{2 4 0 3}$ & $\mathbf{2 1 0 1}$ & $\mathbf{1 9 3 3}$ & $\mathbf{1 5 8 5}$ \\
\hline
\end{tabular}

In the order of Tomatoes: Mangoes: Carrots $A=100: 0: 0 \quad B=90: 5: 5 \quad C=80: 15: 5 \quad D=70: 25: 5$ $\mathrm{E}=60: 35: 5 \mathrm{~F}=50: 45: 5$

When the six treatments were subjected to sensory evaluation, results showed that treatment $\mathrm{C}$ was most accepted by consumers while treatment $\mathrm{E}$ had the least mean acceptance. However, from Duncan's multiple range test results, it is evident that there is no significant difference in acceptability between treatment $\mathrm{A}$ and $\mathrm{C}$, treatment $\mathrm{B}$ and $\mathrm{D}$ and there was a slight similarity between $\mathrm{E}$ and F. Treatment A had the best appearance and color followed by treatment $\mathrm{B}$ and $\mathrm{F}$ had the worst. The goodness of appearance is attributed to the ketchup red color that is as a result of lycopene levels (Shi, Kakuda et al. 2004, Intelmann, Jaros et al. 2005) from tomato pulp. The decreasing amount of tomato pulp in the treatments from $\mathrm{A}$ to $\mathrm{F}$ caused the color deterioration from A to F. Treatment $\mathrm{C}$ and $\mathrm{A}$ had the best taste and flavor and $\mathrm{F}$ the worst. Duncan's multiple range test shows that there is no significant difference in the flavor and taste of treatment $\mathrm{C}$ and $\mathrm{A}$ however, that of treatment $\mathrm{C}$ was slightly higher and this can be attributed to the presence of a significant number of mangoes.

\subsection{Functional Properties of Ketchup Under Various Processing Conditions}

\subsubsection{Viscosity}

The values of viscosity were affected by the changes in time and temperature as shown in Table 5 below. The analysis of variance and Duncan's multiple range test showed that there was a significant difference in the viscosities at different holding temperatures with P-value of 2e-16 $(p \leq 0.05)$ since all viscosity values at the different temperatures had different letters from Duncan's multiple range tables. Duncan's multiple range test also shows that there was a significant difference between the viscosities at the different holding times with P-value of $1.14 \mathrm{e}-09(\mathrm{p} \leq 0.05)$ with all the viscosity values having a different letter ' $a$ ', ' $b$ ' and ' $c$ ' respectively.

Viscosity of the treatments increased greatly with increasing holding temperature and increased slightly with time. This trend is attributed to the fact that increasing temperature and holding time results in moisture loss from the treatments which increases their 


\section{Macrothink}

concentration and hence and increase in viscosity(Koocheki, Ghandi, Razavi, Mortazavi, \& Vasiljevic, 2009). The increase in viscosity can also be attributed to the decrease in intermolecular distances after cooling because of thermal contraction (Azoubel, Cipriani, El-Aouar, Antonio, \& Murr, 2005).

Table 5. Showing the values of viscosity at the different holding times and temperature

\begin{tabular}{llll}
\hline Holding Time & 5 Mins & 10 Mins & 15 Mins \\
\hline Holding Temperature $\left({ }^{\circ} \mathrm{C}\right)$ & Viscosity $(\mathrm{cP})$ & Viscosity $(\mathrm{cP})$ & Viscosity $(\mathrm{cP})$ \\
\hline 100 & $219333 \pm 7696$ & $233333 \pm 577$ & $236533 \pm 1501$ \\
90 & $188833 \pm 1041$ & $191533 \pm 416$ & $197167 \pm 1387$ \\
85 & $162067 \pm 709$ & $150867 \pm 6185$ & $168200 \pm 1375$ \\
80 & $152700 \pm 656$ & $147067 \pm 5845$ & $162067 \pm 1795$ \\
75 & $87467 \pm 208$ & $89333 \pm 1193$ & $101967 \pm 7157$ \\
70 & $64800 \pm 173$ & $69833 \pm 850$ & $78867 \pm 153$ \\
\hline
\end{tabular}

Table 4. Showing the level of significant difference at the different temperatures

\begin{tabular}{lllllll}
\hline Temperature & 100 & 90 & 85 & 80 & 75 & 70 \\
\hline \multirow{3}{*}{ Viscosity } & 229733.3 & 192511.1 & 160377.8 & 153944.4 & 92922.22 & 71166.67 \\
& $\mathrm{a}$ & $\mathrm{b}$ & $\mathrm{c}$ & $\mathrm{d}$ & $\mathrm{e}$ & $\mathrm{f}$ \\
\hline
\end{tabular}

Table 5. Showing the level of significant difference at the different times

\begin{tabular}{llll}
\hline Time & 15 & 10 & 5 \\
\hline Viscosity & $157466.7 \mathrm{a}$ & $146994.4 \mathrm{~b}$ & $145866.7 \mathrm{c}$ \\
\hline
\end{tabular}

Means with the same letter in above tables are not significantly different $(\mathrm{p} \leq 0.05)$.

Viscosity of the treatments increased greatly with increasing holding temperature and increased slightly with time. This trend is attributed to the fact that increasing temperature and holding time results in moisture loss from the treatments which increases their concentration and hence and increase in viscosity (Koocheki, Ghandi et al., 2009). The increase in viscosity can also be attributed to the decrease in intermolecular distances after cooling because of thermal contraction (Azoubel, Cipriani et al., 2005).

The following model can be derived to predict the behavior of viscosity with time and temperature;

$$
\begin{gathered}
\text { Viscosity }=134560.08+5240 * \text { Time }+31014 * \text { Temperature } \\
\text { R squared }=0.9534 \text { Adjusted R squared }=0.9276
\end{gathered}
$$




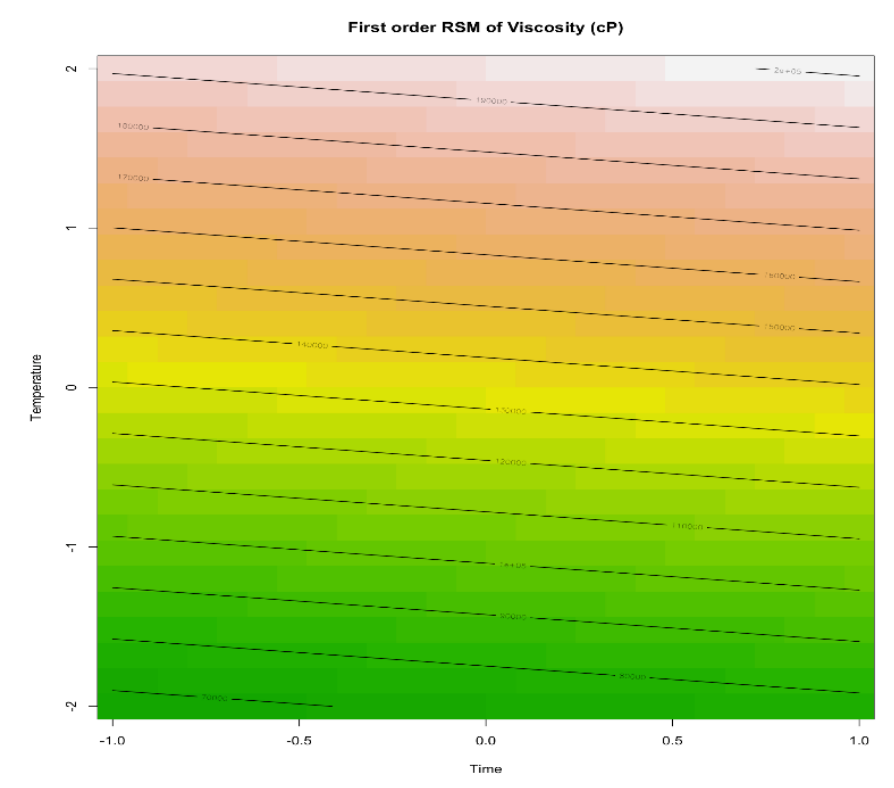

Figure 1. First order response surface for the behavior of viscosity with changes in time and temperature

The color change from the green zone to the light zone shows how increase in temperature and time leads to an increase in viscosity. However, the effect of temperature is more visible showing that viscosity is more affected by processing temperatures rather that processing time.

\subsubsection{TSS}

Analysis of variance showed that there was a slight significant difference between the total soluble solids for the different holding temperatures with P-value of $0.05(\mathrm{p} \leq 0.05)$. This was also confirmed through mean separation using Duncan's multiple range test which indicated TSS values at $80^{\circ} \mathrm{C}$ and $90^{\circ} \mathrm{C}$ with the letter "a" which shows no significant difference. There was also no significant difference between the TSS values at $90^{\circ} \mathrm{C}$ and $85^{\circ} \mathrm{C}, 85^{\circ} \mathrm{C}$ and $100^{\circ} \mathrm{C}$, $70^{\circ} \mathrm{C}$ and $75^{\circ} \mathrm{C}$. However, there was a significant difference between TSS values at $70^{\circ} \mathrm{C}$ and $80^{\circ} \mathrm{C}$ since they have different letters ' $b$ ' and ' $a$ ' respectively.

There was no significant difference between the TSS values at the different holding times with a P-value of $0.766(p \leq 0.05)$. The Duncan's multiple range test also indicates the same at $p \leq 0.05$ which shows all the TSS values having the same letter ' $a$ ' indicating lack of significant difference.

The effect of temperature and time on TSS of ketchup after cooling. It was observed that TSS of ketchup increased with increase in temperature and holding time to a maximum of 31 ${ }^{0} \mathrm{Brix}$ due to increasing moisture loss as a result of increasing temperature and holding time then remained relatively constant up to $95^{\circ} \mathrm{C}$ due to increased inhibition of water loss by the increasing concentration of dietary fiber 


\section{Macrothink}

Table 6. Values of TSS at the different holding times and temperature

\begin{tabular}{llll}
\hline Holding Time & 5 Mins & 10 Mins & 15 Mins \\
\hline Holding Temperature $\left({ }^{\circ} \mathrm{C}\right)$ & TSS $(\%)$ & TSS $(\%)$ & TSS $(\%)$ \\
\hline 100 & $30.0 \pm 1.2$ & $29.5 \pm 2.2$ & $29.7 \pm 2.0$ \\
90 & $30.7 \pm 1.6$ & $30.8 \pm 1.1$ & $30.3 \pm 1.4$ \\
85 & $30.3 \pm 1.3$ & $29.3 \pm 0.3$ & $30.0 \pm 1.1$ \\
80 & $30.7 \pm 0.8$ & $30.9 \pm 0.9$ & $30.3 \pm 0.4$ \\
75 & $30.4 \pm 1.3$ & $29.6 \pm 0.7$ & $28.2 \pm 0.1$ \\
70 & $28.1 \pm 1.4$ & $29.5 \pm 1.0$ & $30.0 \pm 0.3$ \\
\hline
\end{tabular}

Table 7. Showing the level of significant difference at the different temperatures

\begin{tabular}{lllllll}
\hline Temperature & 80 & 90 & 85 & 100 & 75 & 70 \\
\hline TSS & $30.64 \mathrm{a}$ & $30.61 \mathrm{a}$ & $29.84 \mathrm{ab}$ & $29.74 \mathrm{ab}$ & $29.38 \mathrm{~b}$ & $29.20 \mathrm{~b}$ \\
\hline
\end{tabular}

Means with the same letter are not significantly different $(\mathrm{p} \leq 0.05)$.

Table 8. Showing the level of significant difference at the different times

\begin{tabular}{llll}
\hline Holding time & 5 & 10 & 15 \\
\hline TSS & $30.02 \mathrm{a}$ & $29.94 \mathrm{a}$ & $29.74 \mathrm{a}$ \\
\hline
\end{tabular}

Means with the same letter are not significantly different $(\mathrm{p} \leq 0.05)$.

It was observed that TSS of ketchup increased with increase in temperature and holding time to a maximum of $31{ }^{0}$ Brix due to increasing moisture loss as a result of increasing temperature and holding time then remained relatively constant up to $95^{\circ} \mathrm{C}$ due to increased inhibition of water loss by the increasing concentration of dietary fiber.

The following first order model is derived;

TSS $=29.94+0.32667 *$ Temperature

$\mathrm{R}$ squared $=0.3218 \quad$ Adjusted $\mathrm{R}$ squared $=0.2088$

However its $\mathrm{R}$ squared value is significantly below the recommended value for a good model of at least 0.8 hence it's not a good model. 


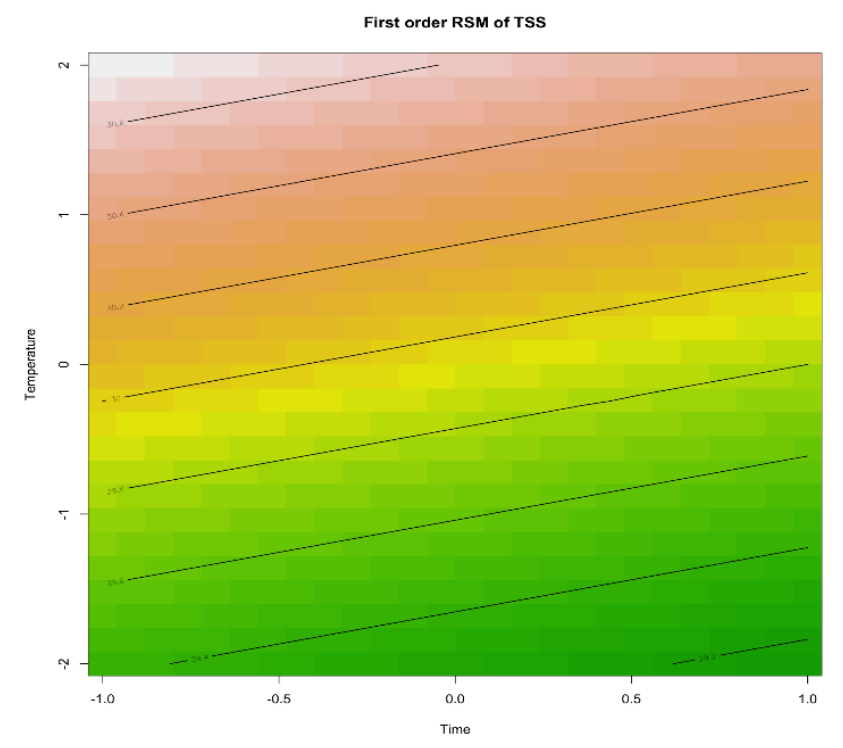

Figure 2. First order response surface for behaviour of TSS with change in temperature and time

The color change from the green zone to the light zone shows how increase in temperature and time leads to an increase in total soluble solids. However, the effect of temperature is stronger and the graphs show that limited exposure to high temperatures leads to an increase in total soluble solids.

\subsubsection{Syneresis}

From the analysis of variance, there was a highly significant difference between the values of Syneresis at the different holding temperatures with a P-value of $2 \mathrm{e}-16(\mathrm{p} \leq 0.05)$. The Duncan's multiple range test also indicated that except for the Syneresis values at $80^{\circ} \mathrm{C}$ and $75^{\circ} \mathrm{C}$ with the same letter' which shows no significant difference, all other values of Syneresis are significantly different from each other. Furthermore, there was a slight significant difference between the Syneresis values at the different holding time. Syneresis at 15 minutes was significantly different from that at 5 and 10 minutes which were not significantly different from each other since they have the same letter ' $b$ '.

There was a general increase in syneresis with increasing temperature and holding time ranging between $27 \%$ at $70^{\circ} \mathrm{C}$ and $44 \%$ at about $100^{\circ} \mathrm{C}$. this can be attributed to the reduction of pectin (Athar, Shah, \& Khan, 2000) as a result of reduction in tomato concentration.

Table 9. Values of Syneresis at the different time and temperature

\begin{tabular}{llll}
\hline Holding Time & 5 Mins & 10 Mins & 15 Mins \\
\hline Holding temperature $\left({ }^{\circ} \mathrm{C}\right)$ & Syneresis $(\%)$ & Syneresis $(\%)$ & Syneresis $(\%)$ \\
\hline 100 & $39.9 \pm 2.0$ & $44.2 \pm 2.0$ & $43.9 \pm 2.2$ \\
90 & $38.3 \pm 1.4$ & $41.8 \pm 1.7$ & $40.6 \pm 1.9$ \\
\hline
\end{tabular}




\begin{tabular}{llll}
\hline 85 & $36.7 \pm 1.1$ & $34.0 \pm 1.7$ & $36.8 \pm 1.7$ \\
80 & $34.1 \pm 0.4$ & $31.3 \pm 1.4$ & $34.4 \pm 1.2$ \\
75 & $33.5 \pm 0.1$ & $30.4 \pm 1.3$ & $33.8 \pm 0.5$ \\
70 & $28.7 \pm 0.3$ & $26.5 \pm 1.3$ & $30.0 \pm 0.3$ \\
\hline
\end{tabular}

Table 10. Showing the level of significant difference at the different temperatures

\begin{tabular}{lllllll}
\hline Temperature & 100 & 90 & 85 & 80 & 75 & 70 \\
\hline Syneresis & $42.67613 \mathrm{a}$ & $40.26026 \mathrm{~b}$ & $35.84385 \mathrm{c}$ & $33.27246 \mathrm{~d}$ & $32.54039 \mathrm{~d}$ & $28.40611 \mathrm{e}$ \\
\hline
\end{tabular}

Means with the same letter are not significantly different $(\mathrm{p} \leq 0.05)$

Table 11. Showing the level of significant difference at the different times

\begin{tabular}{llll}
\hline Holding time & 15 & 5 & 10 \\
\hline Syneresis & $36.59357 \mathrm{a}$ & $35.20379 \mathrm{~b}$ & $34.70224 \mathrm{~b}$ \\
\hline
\end{tabular}

Means with the same letter are not significantly different $(\mathrm{p} \leq 0.05)$.

There was a general increase in syneresis with increasing temperature and holding time ranging between $27 \%$ at $70^{\circ} \mathrm{C}$ and $44 \%$ at about $100^{\circ} \mathrm{C}$. This can be attributed to the reduction of pectin (Athar, Shah et al., 2000) as a result of reduction in tomato concentration. The following first order model can be derived;

Syneresis $=34.06+2.69 *$ Temperature $\mathrm{R}$ squared $=0.8473 \quad$ Adjusted $\mathrm{R}$ squared $=0.8219$ 


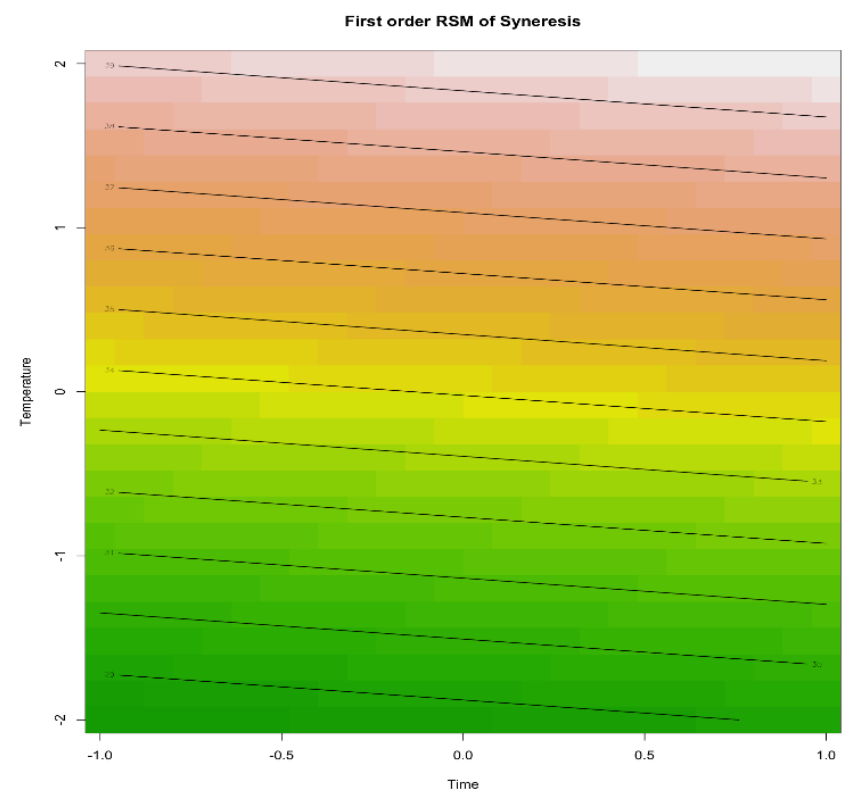

Figure 3. First order response surface for behaviour of syneresis with time and temperature

The color change from the green zone to the light zone shows how increase in temperature and time leads to an increase in syneresis. However, the effect of temperature surpasses the effect of time. Time does not affect the level of syneresis significantly.

\subsubsection{Vitamin C}

After the analysis of variance, the results showed that the values of ascorbic acid at different temperatures were significantly different from each other with a P-value of $2 \mathrm{e}-16(\mathrm{p} \leq 0.05)$. Duncan's multiple range test shows that the ascorbic acid levels at $80^{\circ} \mathrm{C}$ and $85^{\circ} \mathrm{C}$ are not significantly different from each other but significantly different from the rest. Analysis of variance also indicates that the ascorbic acid levels at all holding times were significantly different with a P-value of $1.64 \mathrm{e}-10(\mathrm{p} \leq 0.05)$. Duncan's multiple range test also indicates the same since all values have different letters in Duncan's table.

The levels off vitamin $\mathrm{C}$ decreases with increasing temperature from $75^{\circ} \mathrm{C}$ to $100^{\circ} \mathrm{C}$ which is attributed to the volatile nature of ascorbic acid(Kesselmeier \& Staudt, 1999; Shin, Liu, Nock, Holliday, \& Watkins, 2007).

Table 12. Showing values of Vitamin $\mathrm{C}$ at different holding time and temperature

\begin{tabular}{|c|c|c|c|c|c|c|c|}
\hline \multicolumn{2}{|c|}{ Holding Time } & \multicolumn{2}{|l|}{5 Mins } & \multicolumn{2}{|l|}{10 Mins } & \multicolumn{2}{|l|}{15 Mins } \\
\hline $\begin{array}{l}\text { Holding } \\
\left({ }^{\circ} \mathrm{C}\right)\end{array}$ & Temperature & $\begin{array}{l}\text { Vitamin } \\
(\mathrm{mg} / 100 \mathrm{~g})\end{array}$ & $\mathrm{C}$ & $\begin{array}{l}\text { Vitamin } \\
(\mathrm{mg} / 100 \mathrm{~g})\end{array}$ & $\mathrm{C}$ & $\begin{array}{l}\text { Vitamin } \\
(\mathrm{mg} / 100 \mathrm{~g})\end{array}$ & $\mathrm{C}$ \\
\hline 100 & & $159.5 \pm 4.1$ & & $153.2 \pm 1.2$ & & $150.3 \pm 1.5$ & \\
\hline 90 & & $165.3 \pm 3.2$ & & $161.1 \pm 1.8$ & & $155.8 \pm 4.1$ & \\
\hline 85 & & $169.0 \pm 4.8$ & & $165.3 \pm 1.9$ & & $160.1 \pm 2.9$ & \\
\hline
\end{tabular}




\begin{tabular}{llll}
\hline 80 & $171.0 \pm 2.3$ & $167.1 \pm 0.3$ & $163.8 \pm 2.4$ \\
75 & $173.7 \pm 3.5$ & $170.6 \pm 3.3$ & $166.7 \pm 2.7$ \\
70 & $178.8 \pm 2.4$ & $174.3 \pm 4.3$ & $169.9 \pm 5.8$ \\
\hline
\end{tabular}

Table 13. Showing the level of significant difference at the different temperatures

\begin{tabular}{lllllll}
\hline Holding temperature & 70 & 75 & 80 & 85 & 90 & 100 \\
\hline Vitamin C & $174.31 \mathrm{a}$ & $170.32 \mathrm{~b}$ & $167.29 \mathrm{c}$ & $164.8^{\circ} \mathrm{C}$ & $160.74 \mathrm{~d}$ & $154.33 \mathrm{e}$ \\
\hline
\end{tabular}

Means with the same letter are not significantly different $(\mathrm{p} \leq 0.05)$.

Table 14. Showing the level of significant difference at the different times

\begin{tabular}{llll}
\hline Holding time & 5 & 10 & 15 \\
\hline vitamin C & $169.5505 \mathrm{a}$ & $165.2548 \mathrm{~b}$ & $161.1008 \mathrm{c}$ \\
\hline
\end{tabular}

Means with the same letter are not significantly different $(\mathrm{p} \leq 0.05)$.

The levels off vitamin $\mathrm{C}$ decreases with increasing temperature from $75^{\circ} \mathrm{C}$ to $100^{\circ} \mathrm{C}$ which is attributed to the volatile nature of ascorbic acid (Kesselmeier and Staudt 1999, Shin, Liu et al. 2007).

The following first order model can be deduced respectively;

Vitamin C $=167.62$ - 4.15*Time - 3.2733*Temperature

$\mathrm{R}$ squared $=0.9893$ and Adjusted $\mathrm{R}$ squared $=0.9875$ 


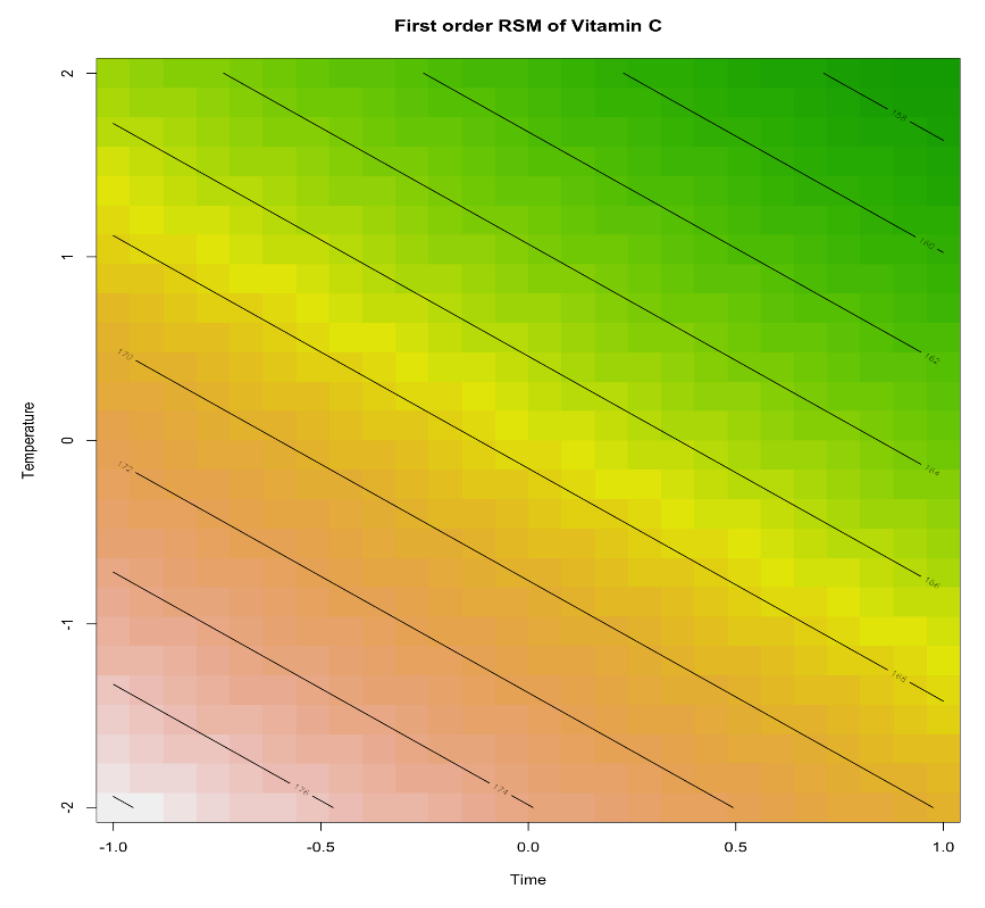

Figure 4. First order response surface for behaviour of vitamin $\mathrm{C}$ with time and temperature

The uniform rapid change in color from light pink in the lower left corner to dark green in the upper right corner shows that both time and temperature negatively affect the quantities of vitamin $\mathrm{C}$ by equal proportions

\subsubsection{Total Carotenoids}

The analysis of variance showed that there was a significant impact of temperature on the levels of total carotenoids with a P-value of $1.62 \mathrm{e}-10(\mathrm{p} \leq 0.05)$. There was also a slight difference between the different levels of total carotenoids at the different holding temperatures according to Duncan's multiple range test.

There was a reduction in the levels of total carotenoids with increasing temperature. carotenes are volatile in nature and hence greatly affected by temperature increase which explains the decreasing levels as the temperature was being increased (Lee \& Chen, 2002).

Table 15. Showing values of total carotenoids at different times and temperatures

\begin{tabular}{llll}
\hline Holding Time & 5 Mins & 10 Mins & 15 Mins \\
\hline Holding Temperature $\left({ }^{\circ} \mathrm{C}\right)$ & Total Carotenoids & Total Carotenoids & Total Carotenoids \\
\hline 100 & $0.7 \pm 0.08$ & $0.7 \pm 0.08$ & $0.6 \pm 0.12$ \\
90 & $0.8 \pm 0.08$ & $0.7 \pm 0.08$ & $0.6 \pm 0.12$ \\
85 & $0.8 \pm 0.01$ & $0.8 \pm 0.08$ & $0.7 \pm 0.04$ \\
80 & $0.9 \pm 0.01$ & $0.8 \pm 0.04$ & $0.8 \pm 0.07$ \\
75 & $0.9 \pm 0.04$ & $0.9 \pm 0.02$ & $0.8 \pm 0.08$ \\
\hline
\end{tabular}


Table 16. Showing the level of significant difference at the different temperature

\begin{tabular}{lllllll}
\hline Holding temperature & 70 & 75 & 80 & 85 & 90 & 100 \\
\hline Total Carotenoids & $0.92 \mathrm{a}$ & $0.87 \mathrm{ab}$ & $0.830 \mathrm{bc}$ & $0.778 \mathrm{c}$ & $0.711 \mathrm{~d}$ & $0.664 \mathrm{~d}$ \\
\hline
\end{tabular}

Means with the same letter are not significantly different $(\mathrm{p} \leq 0.05)$.

Table 17. Showing the level of significant difference at the different times

\begin{tabular}{llll}
\hline Time & 5 & 10 & 15 \\
\hline Total Carotenoids & $0.851 \mathrm{a}$ & $0.810 \mathrm{a}$ & $0.727 \mathrm{~b}$ \\
\hline
\end{tabular}

Means with the same letter are not significantly different $(\mathrm{p} \leq 0.05)$.

There was a reduction in the levels of total carotenoids with increasing temperature. Lycopenes are volatile in nature and hence greatly affected by temperature increase which explains the decreasing levels as the temperature was being increased (Lee \& Chen, 2002).

The following first order models are deduced respectively;

Total carotenoids $=0.82-0.06 *$ Time $-0.0567 *$ Temperature

$\mathrm{R}$ squared $=0.919$ and Adjusted $\mathrm{R}$ squared $=0.9055$

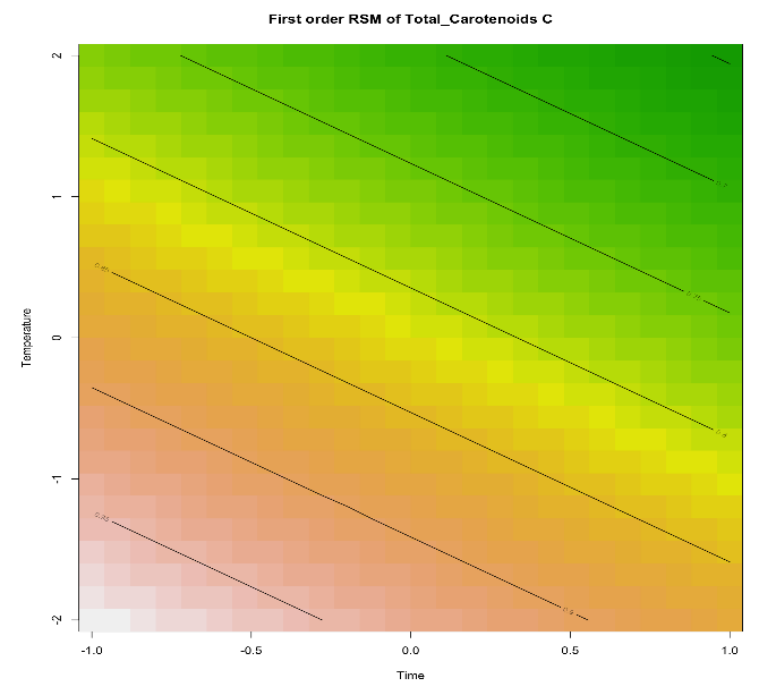

Figure 5. First order response surface for behaviour of total carotenoids with time and temperature

Figure above is a graphical representative of the first and second order response surface models showing how total carotenoids vary with time and temperature. The uniform gentle change in color from light pink in the lower left corner to dark green in the upper right corner shows that both time and temperature negatively affect the quantities of total carotenoids by equal proportions. 


\section{Macrothink}

\section{Conclusions}

Addition of mangoes and carrots to the tomato ketchup significantly improved the nutritional properties of the ketchup with the largest increase being observed in soluble sugars and ascorbic acid. The viscosity of the ketchup also increased with addition of mangoes and carrots decreasing flowability. Product processing conditions are essential in determining the quality of ketchup. Processing temperatures above $85^{\circ} \mathrm{C}$ highly reduce the nutritional quality of ketchup as it significantly reduces the concentrations of vitamin $\mathrm{C}$ and total carotenoids. It's safe to process ketchup at temperatures between $80^{\circ} \mathrm{C}$ and $85^{\circ} \mathrm{C}$ for about 10 to 15 minutes holding time in order to achieve high nutritional value. Processing conditions have no significant effect on the $\mathrm{pH}$ of the ketchup as it's mostly affected by the components of the ketchup and additives.

\section{Acknowledgment}

The authors thank Reduction of Post-harvest and Value Addition (RELOAD) project under Makerere University for funding this research.

\section{References}

Abu-Jdayil, B. (2004). A comparative study of rheological characteristics of tomato paste and tomato powder solutions. International Journal of Food Properties, 7(3), 483-497. https://doi.org/10.1081/JFP-200032940

Athar, I. H. (2000). Effect of various stabilizers on whey separation (syneresis) and quality of yoghurt. Pakistan Journal of Biological Sciences (Pakistan).

Azoubel, P. M. (2005). Effect of concentration on the physical properties of cashew juice. Journal of Food Engineering, 66(4), 413-417. https://doi.org/10.1016/j.jfoodeng.2004.04.008 Banga, J. R. (2003). Improving food processing using modern optimization methods. Trends in Food Science \& Technology, 14(4), 131-144. https://doi.org/10.1016/S0924-2244(03)00048-7

Baş, D., \& Boyac1, İ. H. (2007). Modeling and optimization, I: Usability of response surface methodology. Journal of Food Engineering, 78(3), 836-845. https://doi.org/10.1016/j.jfoodeng. 2005.11.024

Beresovsky, N. (1995). The role of pulp interparticle interaction in determining tomato juice viscosity. Journal of Food Processing and Preservation, 19(2), 133-146. https://doi.org/10.1111/j.1745-4549.1995.tb00283.x

Bezerra, M. A. (2008). Response surface methodology (RSM) as a tool for optimization in analytical chemistry. Talanta, 76(5), 965-977. https://doi.org/10.1016/j.talanta.2008.05.019

Box, G. E., \& Draper, N. R. (2007). Response surfaces, mixtures, and ridge analyses. John Wiley \& Sons. https://doi.org/10.1002/0470072768

Bulda, O. (2008). Spectrophotometric measurement of carotenes, xanthophylls, and chlorophylls in extracts from plant seeds. Russian Journal of Plant Physiology, 55(4), 544. https://doi.org/10.1134/S1021443708040171

Cooke, M. C. (1891). British edible fungi: how to distinguish and how to cook them. Kegan Paul, Trench, Trübner \& Company Limited. https://doi.org/10.5962/bhl.title.3892

Coupland, J. (2014). An Introduction to the Physical Chemistry of Food, Springer. https://doi.org/10.1007/978-1-4939-0761-8 


\section{MInstitute ${ }^{\text {Mink }}$}

Cullen, P. (2001). In-line consistency monitoring of tomato-based products using vibrational process viscometry. Journal of Food Processing and Preservation, 25(5), 337-351. https://doi.org/10.1111/j.1745-4549.2001.tb00465.x

De Aguiar, P. F. (1995). D-optimal designs. Chemometrics and Intelligent Laboratory Systems, 30(2), 199-210. https://doi.org/10.1016/0169-7439(94)00076-X

Den Ouden, F. (1995). Physico-chemical stability of tomato products, Den Ouden.

Dickinson, E. (2003). Hydrocolloids at interfaces and the influence on the properties of dispersed systems. Food Hydrocolloids, 17(1), 25-39. https://doi.org/10.1016/S0268-005X (01)00120-5

Dziezak, J. D. (1991). A focus on gums. Food Technol., 45, 116-132.

Garti, N., \& Reichman, D. (1993). Hydrocolloids as food emulsifiers and stabilizers. Food Structure, 12(4), 3.

Gladwell, M. (2009). What the dog saw: And other adventures, Hachette UK.

Glicksman, M. (1979). Gelling hydrocolloids in food product applications. Proceedings. https://doi.org/10.1016/B978-0-408-10618-4.50017-2

Glicksman, M. (1991). Hydrocolloids and search for the" Oily Grail. Food Technol.-October: 94-103.

Guillou, A. A., \& Floros, J. D. (1993). Multiresponse optimization minimizes salt in natural cucumber fermentation and storage. Journal of Food Science, 58(6), 1381-1389. https://doi.org/10.1111/j.1365-2621.1993.tb06188.x

Gujral, H. S. (2002). Effect of hydrocolloids, storage temperature, and duration on the consistency of tomato ketchup. International Journal of Food Properties, 5(1), 179-191. https://doi.org/10.1081/JFP-120015600

Haley, T. A., \& Smith, R. S. (2003). Evaluation of in-line absorption photometry to predict consistency of concentrated tomato products. LWT-Food Science and Technology, 36(2), 159-164. https://doi.org/10.1016/S0023-6438(02)00218-9

Hinrichs, R. (2003). Water-holding capacity and structure of hydrocolloid-gels, WPC-gels and yogurts characterized by means of NMR. Food chemistry, 82(1), 155-160. https://doi.org/10.1016/S0308-8146(02)00539-3

Hoefler, A. C., \& Favorite, (2004). Introduction to food hydrocolloids, Eagan Press, St. Paul.

Hu, R. (1999). Food product design: a computer-aided statistical approach, CRC Press.

Intelmann, D. (2005). Identification of color optima of commercial tomato catsup. European Food Research and Technology, 221(5), 662. https://doi.org/10.1007/s00217-005-0048-4

Jay, J. M. (1998). Intrinsic and extrinsic parameters of foods that affect microbial growth. Modern food microbiology, Springer. https://doi.org/10.1007/978-1-4615-7476-7_3

Journel, A. G., \& Deutsch, C. V. (1993). Entropy and spatial disorder. Mathematical Geology, 25(3), 329-355. https://doi.org/10.1007/BF00901422

Juszczak, L. (2013). Effect of modified starches on rheological properties of ketchup. Food and Bioprocess Technology, 6(5), 1251-1260. https://doi.org/10.1007/s11947-012-0813-x

Kalil, S. (2000). Response surface analysis and simulation as a tool for bioprocess design and 
optimization. Process Biochemistry, 35(6), 539-550. https://doi.org/10.1016/S0032-9592 (99)00101-6

Kesselmeier, J., \& Staudt, M. (1999). Biogenic volatile organic compounds (VOC): an overview on emission, physiology and ecology. Journal of Atmospheric Chemistry, 33(1), 23-88. https://doi.org/10.1023/A:1006127516791

Khuri, A. I., \&Mukhopadhyay, S. (2010). Response surface methodology. Wiley Interdisciplinary Reviews: Computational Statistics, 2(2), 128-149. https://doi.org/10.1002/ wics. 73

Koocheki, A. (2009). The rheological properties of ketchup as a function of different hydrocolloids and temperature. International journal of food science \& technology, 44(3), 596-602.

La Pena, R. D., \& Hughes, J. (2007). Improving vegetable productivity in a variable and changing climate.

Lawrence, A. (1959). Syneresis of rennet curd: Part I-Effect of time and temperature. Australian Journal of Dairy Technology, 14(4), 166.

Lee, M., \& Chen, B. (2002). Stability of lycopene during heating and illumination in a model system. Food Chemistry, 78(4), 425-432. https://doi.org/10.1016/S0308-8146(02)00146-2

Liyana-Pathirana, C., \&Shahidi, F. (2005). Optimization of extraction of phenolic compounds from wheat using response surface methodology. Food chemistry, 93(1), 47-56. https://doi.org/10.1016/j.foodchem.2004.08.050

Malkin, A. Y. (2013). Non-Newtonian viscosity in steady-state shear flows. Journal of Non-Newtonian Fluid Mechanics, 192, 48-65. https://doi.org/10.1016/j.jnnfm.2012.09.015

Malundo, T. (2001). Sugars and acids influence flavor properties of mango (Mangifera indica). Journal of the American Society for Horticultural Science, 126(1), 115-121. https://doi.org/10.21273/JASHS.126.1.115

Mattoo, A., \& Modi, V. (1970). Citrate cleavage enzyme in mango fruit. Biochemical and biophysical research communications, 39(5), 895-904. https://doi.org/10.1016/0006-291X (70)90408-0

McDonald, K., \& Sun, D.-W. (1999). Predictive food microbiology for the meat industry: a review. International journal of food microbiology, 52, 1-27. https://doi.org/10.1016/S01681605(99)00126-9

Montgomery, D. C. (2008). Design and analysis of experiments, John Wiley \& Sons.

Moretti, C. (2010). Climate changes and potential impacts on postharvest quality of fruit and vegetable crops: a review. Food Research International, 43(7), 1824-1832. https://doi.org/10.1016/j.foodres.2009.10.013

Peričin, D. (2008). Evaluation of solubility of pumpkin seed globulins by response surface method. Journal of food engineering, 84(4), 591-594. https://doi.org/10.1016/j.jfoodeng.2007. 07.002

Porretta, S. (1995). Effects of ultra-high hydrostatic pressure treatments on the quality of tomato juice. Food chemistry, 52(1), 35-42. https://doi.org/10.1016/0308-8146(94)P4178-I

Poste, L. M. (1991). Laboratory methods for sensory analysis of food, Canada Communication 


\section{Macrothink}

Group.

Sablani, S. S. (2008). Status of observational models used in design and control of products and processes. Comprehensive Reviews in Food Science and Food Safety, 7(1), 130-136. https://doi.org/10.1111/j.1541-4337.2007.00031.x

Şahin, H., \& Özdemir, F. (2007). Effect of some hydrocolloids on the serum separation of different formulated ketchups. Journal of food engineering, 81(2), 437-446. https://doi.org/10.1016/j.jfoodeng.2006.11.022

Sahlin, E. (2004). Investigation of the antioxidant properties of tomatoes after processing. Journal of Food composition and Analysis, 17(5), 635-647. https://doi.org/10.1016/ j.jfca.2003.10.003

Sanchez, M. C. (2002). Influence of processing on the rheological properties of tomato paste. Journal of the Science of Food and Agriculture, 82(9), 990-997. https://doi.org/10.1002/ jsfa. 1141

Sapir, L., \& Harries, D. (2015). Is the depletion force entropic? Molecular crowding beyond steric interactions. Current Opinion in Colloid \& Interface Science, 20(1), 3-10. https://doi.org/10.1016/j.cocis.2014.12.003

Shah, K. (2010). Mangifera indica (mango). Pharmacognosy reviews, 4(7), 42. https://doi.org/10.4103/0973-7847.65325

Shi, J. (2004). Antioxidative properties of lycopene and other carotenoids from tomatoes: synergistic effects. Biofactors, 21(1-4), 203-210. https://doi.org/10.1002/biof.552210141

Shin, Y. (2007). Temperature and relative humidity effects on quality, total ascorbic acid, phenolics and flavonoid concentrations, and antioxidant activity of strawberry. Postharvest Biology and Technology, 45(3), 349-357. https://doi.org/10.1016/j.postharvbio.2007.03.007

Sidhu, J. S. (1997). Studies on the effect of hydrocolloids on the consistency of tomato ketchup. Journal of Food science and Technology, 34(5), 423-424.

Smith, A. F. (1996). Pure ketchup: a history of America's national condiment, with recipes, Univ of South Carolina Press.

Stoforos, N. G., \& Reid, D. S. (1990). A test for evaluation of the serum separation potential of tomato ketchup. Journal of Food Science, 55(6), 1626-1629. https://doi.org/10.1111/j.13652621.1990.tb03586.x

Thybo, A. K. (2005). "Integration of sensory and objective measurements of tomato quality: quantitative assessment of the effect of harvest date as compared with growth medium (soil versus rockwool), electrical conductivity, variety and maturity. Journal of the Science of Food and Agriculture, 85(13), 2289-2296. https://doi.org/10.1002/jsfa.2253

Unal, R. (1998). Response surface model building and multidisciplinary optimization using D-optimal designs. 7th AIAA/USAF/NASA/ISSMO Symposium on Multidisciplinary Analysis and Optimization. https://doi.org/10.2514/6.1998-4759

UNIDO (2004). Small-scale Fruit and Vegetable Processing and Products. Unido Technology Manual.

Wu, Y. (2002). Experiment design and data processing. Press of Suzhou University: SuZhou, China. 
Zandieh, M. (2009). A robust parameter design for multi-response problems. Journal of computational and applied mathematics, 230(2), 463-476. https://doi.org/10.1016/j.cam. 2008.12.019

Athar, I. H., Shah, M. A., \& Khan, U. (2000). Effect of various stabilizers on whey separation (syneresis) and quality of yoghurt. Pakistan Journal of Biological Sciences (Pakistan).

Ayo, S. A., Bonabana-Wabbi, J., \& Sserunkuuma, D. (2012). Determinants of fast food consumption in Kampala, Uganda. African Journal of Food, Agriculture, Nutrition and Development, 12(5), 6567-6581.

Azoubel, P. M., Cipriani, D. C., El-Aouar, Â. A., Antonio, G. C., \& Murr, F. E. X. (2005). Effect of concentration on the physical properties of cashew juice. Journal of food engineering, 66(4), 413-417. https://doi.org/10.1016/j.jfoodeng.2004.04.008

Boateng, A. B. (2016). Determinants of postharvest loss in maize-a case study of Ejura-Sekyedumasi Municipality of Ashanti Region of Ghana.

Castro, I., Teixeira, J. A., Salengke, S., Sastry, S. K., \& Vicente, A. A. (2004). Ohmic heating of strawberry products: electrical conductivity measurements and ascorbic acid degradation kinetics. Innovative Food Science \& Emerging Technologies, 5(1), 27-36. https://doi.org/10.1016/j.ifset.2003.11.001

Eggersdorfer, M., \& Wyss, A. (2018). Carotenoids in human nutrition and health. Archives of biochemistry and biophysics, 652, 18-26. https://doi.org/10.1016/j.abb.2018.06.001

Gillberg, L., Ørskov, A. D., Liu, M., Harsløf, L. B., Jones, P. A., \& Grønbæk, K. (2018). Vitamin C-A new player in regulation of the cancer epigenome. Paper presented at the Seminars in cancer biology. https://doi.org/10.1016/j.semcancer.2017.11.001

Haugen, M., Lillegaard, I. T. L., Frøyland, L., Holvik, K., Løvik, M., Strand, T. A., . . Iversen, P. O. (2018). Assessment of Dietary Intake of Vitamin C and Calcium in the Norwegian Population. European Journal of Nutrition \& Food Safety, 233-236. https://doi.org/10.9734/EJNFS/2018/43855

Kesselmeier, J., \& Staudt, M. (1999). Biogenic volatile organic compounds (VOC): an overview on emission, physiology and ecology. Journal of atmospheric chemistry, 33(1), 23-88. https://doi.org/10.1023/A:1006127516791

Koocheki, A., Ghandi, A., Razavi, S. M., Mortazavi, S. A., \& Vasiljevic, T. (2009). The rheological properties of ketchup as a function of different hydrocolloids and temperature. International journal of food science \& technology, 44(3), 596-602. https://doi.org/10.1111/j.1365-2621.2008.01868.x

Lee, M., \& Chen, B. (2002). Stability of lycopene during heating and illumination in a model system. Food chemistry, 78(4), 425-432. https://doi.org/10.1016/S0308-8146(02)00146-2

Mrad, N. D., Boudhrioua, N., Kechaou, N., Courtois, F., \& Bonazzi, C. (2012). Influence of air drying temperature on kinetics, physicochemical properties, total phenolic content and ascorbic acid of pears. Food and bioproducts processing, 90(3), 433-441. https://doi.org/10.1016/j.fbp.2011.11.009

Murdock, L. L., Margam, V., Baoua, I., Balfe, S., \& Shade, R. E. (2012). Death by desiccation: effects of hermetic storage on cowpea bruchids. Journal of Stored Products Research, 49, 


\section{Macrothink}

166-170. https://doi.org/10.1016/j.jspr.2012.01.002

Naidu, K. A. (2003). Vitamin C in human health and disease is still a mystery? An overview. Nutrition journal, 2(1), 7. https://doi.org/10.1186/1475-2891-2-7

Olajide, J., \& Oyelade, O. (2002). Performance evaluation of the strategic grain reserve storage programme (SGRSP) in Nigeria. Technovation, 22(7), 463-468. https://doi.org/10.1016/ S0166-4972(01)00015-3

Sánchez, C., Baranda, A. B., \& de Marañón, I. M. (2014). The effect of high pressure and high temperature processing on carotenoids and chlorophylls content in some vegetables. Food chemistry, 163, 37-45. https://doi.org/10.1016/j.foodchem.2014.04.041

Saravacos, G. (1970). Effect of temperature on viscosity of fruit juices and purees. Journal of Food Science, 35(2), 122-125. https://doi.org/10.1111/j.1365-2621.1970.tb12119.x

Shin, Y., Liu, R. H., Nock, J. F., Holliday, D., \& Watkins, C. B. (2007). Temperature and relative humidity effects on quality, total ascorbic acid, phenolics and flavonoid concentrations, and antioxidant activity of strawberry. Postharvest Biology and Technology, 45(3), 349-357. https://doi.org/10.1016/j.postharvbio.2007.03.007

\section{Copyright Disclaimer}

Copyright for this article is retained by the author(s), with first publication rights granted to the journal.

This is an open-access article distributed under the terms and conditions of the Creative Commons Attribution license (http://creativecommons.org/licenses/by/4.0/). 